DOI: 10.36695/2219-5521.4.2020.42

УДК $347.424 ; 336.717 .3$

\title{
О.О. МЕЛЬНИК
}

Ольга Олегівна Мельник, кандидат юридичних наук, адвокат, старший викладач Київського інституту інтелектуальної власності та права Національного університету "Одеська юридична академія»*

ORCID: 0000-0002-2088-630X

\section{ЗМІНА ТА РОЗІРВАННЯ ДОГОВОРУ У ВИПАДКУ ДІЇ ОБСТАВИН ФОРС-МАЖОРУ ВНАСЛІДОК ПАНДЕМІЇ}

Постановка проблеми. Форс-мажор (непереборна сила) може бути причиною істотної зміни обставин, що є підставою для розірвання або зміни договору i, у кінцевому рахунку, призводить до припинення зобов'язання (його розірвання) або збереження зобов'язання у зміненому вигляді. Правове регулювання правових наслідків істотної зміни обставин, які існують при укладенні договору, як правило, будується на основі одного $з$ двох ключових принципів договірного права: принципу, згідно з яким договори мають виконуватись (pacta sunt servanda), або застереженні про незмінність обставин (clausula rebus sic stantibus). У законодавстві зарубіжних країн містяться норми, відповідно до яких «зміна обставин може бути виправданням зміни договору, коли збереження договору у первісному вигляді призводить до надзвичайних результатів, не сумісних із справедливістю» ${ }^{1}$. Основними наслідками істотної зміни обставин, якими сторони керувалися при укладенні договору, $є$ :

- власне зміна договору, тобто зміна умов договору (і як наслідок - зобов'язань між сторонами) при збереженні самого договору в силі;

- розірвання договору за згодою сторін.

На сьогодні в нашій країні, як і в багатьох країнах світу, склалася ситуація, яка унеможливлює виконання договірних зобов'язань, пов'язаних із запровадженням країнами загальнонаціональних карантинів у зв'язку із пандемією коронавірусної хвороби (COVID-19). Уряд нашої держави також вдався до врегулювання ситуації, яка склалася із запровадженням карантину на території України. Це стосується регулювання як економічної, так і соціальної сфери.

Відповідно до Законів України «Про захист населення від інфекційних хвороб» від 6 квітня 2000 р. ${ }^{2}$ та «Про внесення змін до деяких законодавчих актів України, спрямованих на запобігання виникнення і поширення коронавірусної хвороби (COVID-19)» від 17 березня 2020 p. ${ }^{3}$ на території нашої держави введено загальнонаціональний карантин, спрямований на захист населення від коронавірусної хвороби. Запровадження карантинних заходів суттєво вплинуло на роботу всіх без винятку бізнесових структур, призвело до призупинення діяльності багатьох підприємств та унеможливило, у більшості випадків, виконання зобов'язань, у тому числі й цивільно-правових.

Аналіз досліджень, публікацій та нормативних актів. Питання цивільно-правової відповідальності тією чи іншою мірою досліджувалися в літературі з загальної теорії права (С.С. Алєксєєв, у спільній роботі О.С. Йоффе та М.Д. Шаргородського та ін.), а також спеціалістами у галузі цивільного права. 3 робіт, присвячених відповідальності у цивільному праві, слід зазначити наступні. Питання характеру та підстав відповідальності були предметом дослідження Г.Ф. Шершеневича, також, для цілей цього дослідження велике значення мають роботи О.С. Йоффе «Відповідальність за радянським цивільним правом» (1955 р.) та «Зобов'язальне право», у яких автор дає своє визначення цивільно-правової відповідальності і характеризує умови їі настання, приділяючи найбільшу увагу суб'єктивному фактору вини ${ }^{4}$. У роботі В.А. Рахміловича «Про протиправність як підставу цивільної відповідальності» (1964р.) обгрунтовується позиція щодо можливості визнання неправомірною, у тому числі, і такої дії, що не закріплена у нормі права. О.А. Красавчиков у роботі «Відшкодування шкоди, заподіяної джерелом підвищеної небезпеки» (1966р.) надає обгрунтування аспектам відповідальності без вини, наводить різні погляди на цю проблему і робить висновок щодо природи цього явища5.

Визначення ризику як однієї із суб'єктивних підстав відповідальності міститься у праці В.А. Ойгензихта «Проблема ризику у цивільному праві» (1972р.), у якій автор також наводить основні теорії ризику і торкається проблеми обгрунтування відповідальності без вини 6 .

Певні аспекти проблематики дослідження знайшли своє висвітлення у сучасних дисертаційних роботах з питань цивільно-правової відповідальності таких авторів, як: В.А. Хохлов «Цивільно-правова відповідальність за порушення договору», Т.С. Ківалова «Зобов’язання відшкодування шкоди за цивільним законодав-

(C) О.О. Мельник, 2020

* Olha Melnyk, Ph.D. in Law, Lawyer, Senior lecturer of Kyiv Institute of Intellectual property and rights of National University "Odessa Law Academy" 
ством України: теоретичні проблеми», Д.Н. Кархальов «Співвідношення заходів захисту і мір відповідальності у цивільному праві Росії», С.О. Коновалов «Підстава цивільно-правової відповідальності» та ін. 7 Увесь масив наукової літератури з питань вивчення феномена форс-мажору можна поділити на наукові дослідження $з$ римського приватного права, цивільного права дореволюційного, радянського та сучасного періодів (в умовах пандемії) - а саме зміни до Закону України «Про торгово-промислові палати в Україні» від 2 грудня 1997 р. (Відомості Верховної Ради України. 1998. № 13. Ст. 52), прийнятий Закон України «Про захист населення від інфекційних хвороб» від 6 квітня 2000 р. (Відомості Верховної Ради України. 2000. № 29) та прийнятий Закон України «Про внесення змін до деяких законодавчих актів України, спрямованих на запобігання виникнення і поширення коронавірусної хвороби (COVID-19)» від 17 березня 2020 р.

Мета та завдання дослідження. Метою статті $€$ дослідження теоретичних і практичних проблем цивільно-правової категорії «форс-мажор», формулювання пропозицій та висновків, виходячи із проаналізованого матеріалу, вивчення категорії форс-мажором (непереборною силою), комерційний ризик та їх розмежування, склалася ситуація, яка унеможливлює виконання договірних зобов'язань, пов'язаних із запровадженням країнами загальнонаціональних карантинів у зв'язку із пандемією коронавірусної хвороби (COVID-19).

Для досягнення мети були поставлено таке завдання:

1. Дослідити, як в умовах пандемія відбувається укладення договорів, чи можемо вважати коронавірус форс-мажором.

Виклад основного матеріалу. Карантин як форс-мажсона обставина в договірних зобов'язаннях.

У науковій літературі зазначається, що ст. 652 ЦК України є однією із найбільш дискусійних у науці цивільного права України та на практиці ${ }^{8}$.

Відповідно до ст. 652 ЦК України істотна зміна обставин, з яких сторони виходили при укладенні договору, є підставою для його зміни або розірвання, якщо інше не передбачено договором або не випливає із суті зобов'язання. При цьому зміна обставин визнається істотною, коли вони змінилися настільки, що, якби сторони могли це розумно передбачити, договір взагалі не був би ними укладений або був би укладений на умовах, що значно відрізняються.

Відповідно до ч. 2 ст. 652 ЦК України для зміни або розірвання договору на підставі істотної зміни обставин необхідною є наявність чотирьох умов:

1) в момент укладення договору сторони виходили з того, що така зміна обставин не настане;

2) зміна обставин зумовлена причинами, які заінтересована сторона не могла усунути після їх виникнення при всій турботливості та обачливості, які від неї вимагалися;

3) виконання договору порушило б співвідношення майнових інтересів сторін і позбавило б заінтересовану сторону того, на що вона розраховувала при укладенні договору;

4) із суті договору або звичаїв ділового обороту не випливає, що ризик зміни обставин несе заінтересована сторона.

Якщо сторони не досягли згоди щодо приведення договору у відповідність з обставинами, які істотно змінились, або щодо його розірвання, договір може бути розірваний, а 3 підстав, встановлених ч. 4 ст. 652 ЦК України, - змінений за рішенням суду на вимогу заінтересованої сторони за наявності одночасно таких умов: у момент укладення договору сторони виходили з того, що така зміна обставин не настане; зміна обставин зумовлена причинами, які заінтересована сторона не могла усунути після їх виникнення при всій турботливості та обачності, які від неї вимагалися; виконання договору порушило б співвідношення майнових інтересів сторін і позбавило б заінтересовану сторону того, на що вона розраховувала при укладенні договору; із суті договору або звичаїв ділового обороту не випливає, що ризик зміни обставин несе заінтересована сторона. Так, зміна договору у зв'язку з істотною зміною обставин допускається за рішенням суду у виняткових випадках, коли розірвання договору суперечить суспільним інтересам або потягне для сторін шкоду, яка значно перевищує затрати, необхідні для виконання договору на умовах, змінених судом. У разі розірвання договору внаслідок істотної зміни обставин суд, на вимогу будь-якої із сторін, визначає наслідки розірвання договору виходячи з необхідності справедливого розподілу між сторонами витрат, понесених ними у зв'язку з виконанням цього договору.

Слід зазначити, що положення ч. 2 ст. 652 ЦК України також як і у недержавних збірках приватного і договірного права (Принципи європейського договірного права, Принципи міжнародних комерційних договорів УНІДРУА 2010 р.), не покладають на заінтересовану сторону необхідність здійснення (тобто вжиття необхідних засобів) дій щодо подолання причин, які викликала істотна зміна обставин. Аналогічна вимога міститься у ст. 8:108 Принципів європейського договірного права і в п. 1 ст. 79 Конвенції ООН про договори міжнародної купівлі-продажу товарів 1980 р., але тільки щодо обставин непереборної сили / перешкод (ехсиse due to impediment): сторона не несе відповідальність за порушення договору, яке викликане обставиною непереборної сили, яке було поза ії контролем, та яке не могло бути розумно прийнято до уваги під час укладення договору, або яке вона не могла подолати або запобігти.

Решта недержавних збірок приватного і договірного права (Принципи міжнародних комерційних договорів УНІДРУА 2010 р, Принципи європейського договірного права, Принципи, визначення та модельні правила європейського приватного права - Проєкт «загальних критеріїв» DCFR 9 ) передбачають тільки вимогу відсутності причинно-наслідкового зв'язку між зміною обставин і діями заінтересованої сторони.

Відповідно ч. 3 ст. 653 ЦК України у разі зміни або розірвання договору зобов'язання змінюється або припиняється з моменту досягнення домовленості про зміну або розірвання договору, якщо інше не встанов- 
лено договором чи не зумовлено характером його зміни. Якщо договір змінюється або розривається у судовому порядку, зобов'язання змінюється або припиняється з моменту набрання рішенням суду про зміну або розірвання договору законної сили. Таким чином, договір може бути розірваний або змінений, оскільки сторони не могли розумно передбачити відповідні ризики при його укладенні або оскільки прийнятий боржником на себе ризик виявився надзвичайно обтяжливим і в будь-якому випадку істотно порушує майнові інтереси однієї зі сторін ${ }^{10}$.

Отже, при наявності істотної зміни обставин відповідальність сторін зберігається. Це означає, що сторона, право якої порушено, має право вимагати відшкодування збитків. Отже, сторони при розірванні договору в зв'язку з істотно зміненими обставинами можуть вимагати не тільки справедливого розподілу реального збитку, а й упущеної вигоди ${ }^{11}$.

Майже всі цивільно-правові договори містять пункт, який звільняє виконавців договору від відповідальності, а саме, якщо має місце форс-мажорна обставина (дія непереборної сили). Виникає питання: чи можна введення карантину вважати за форс-мажорну обставину?

Законодавці завчасно передбачили виникнення такого питання, а тому Законом України «Про внесення змін до деяких законодавчих актів України, спрямованих на запобігання виникнення і поширення коронавірусної хвороби (COVID-19)» від 17 березня 2020 р. до частини другої ст. 141 Закону України «Про торговопромислові палати в Україні» були внесені відповідні зміни, і карантин було визнано форс-мажюрною обставиною, під якою розуміють надзвичайні та невідворотні обставини, що об' єктивно унеможливлюють виконання зобов'язань, передбачених умовами договору (контракту, угоди тощо) ${ }^{12}$.

Висновок. Запровадження карантинних заходів суттєво вплинуло на роботу всіх без винятку бізнесових структур, призвело до призупинення діяльності багатьох підприємств та унеможливило, у більшості випадків, виконання зобов'язань, у тому числі й цивільно-правових.

Формально процедура визнання карантину форс-мажорною обставиною законодавчо визначена, також відбулися і відповідні зміни в законодавстві. Але наявність форс-мажору не звільняє виконавця за цивільноправовим договором від його виконання, а лише відтерміновує в часі виконання.

Підбиваючи підсумки, виходячи із всього опрацьованого матеріалу, варто сказати, що договори цивільно-правового та господарсько-правового характеру спрямовуються на їх належне виконання. Зміст ст. 526 Цивільного кодексу України (далі - ЦК України) та ст. 193 Господарського кодексу України (далі - ГК України) зводиться до того, що договірні зобов'язання між контрагентами повинні виконуватися належним чином. Інакше винна сторона у невиконанні зобов'язання повинна понести відповідальність.

ЦК України та ГК України передбачають випадки звільнення винної від невиконання зобов'язання сторони від цивільно-правової чи господарсько-правової відповідальності. Йдеться про звільнення від відповідальності у разі факту форс-мажору (непереборної сили) ${ }^{13}$.

На сьогодні в нашій країні, як і у багатьох країнах світу, склалася ситуація, яка унеможливлює виконання договірних зобов'язань, пов'язаних із запровадженням країнами загальнонаціональних карантинів у зв’язку із пандемією коронавірусної хвороби (COVID-19).

Відповідно до Законів України «Про захист населення від інфекційних хвороб» від 6 квітня 2000 р. та «Про внесення змін до деяких законодавчих актів України, спрямованих на запобігання виникнення і поширення коронавірусної хвороби (COVID-19)» від 17 березня 2020 р. на території нашої держави введено загальнонаціональний карантин, спрямований на захист населення від коронавірусної хвороби. Запровадження карантинних заходів суттєво вплинуло на роботу всіх без винятку бізнесових структур, призвело до призупинення діяльності багатьох підприємств та унеможливило, у більшості випадків, виконання зобов'язань, у тому числі й цивільно-правових. Майже всі цивільно-правові договори містять пункт, який звільняє виконавців договору від відповідальності, а саме, якщо має місце форс-мажорна обставина (дія непереборної сили).

Встановлений Урядом карантин визнаватиметься форс-мажором лише у випадку, коли запроваджені ним заходи об'єктивно унеможливлюють виконання зобов'язань, передбачених умовами конкретного договору (контракту, угоди тощо) або законодавчими та іншими нормативними актами.

Наслідки визнання коронавірусу у форс-мажором також залежать від умов договору (наприклад взяти договір про надання послуг з перевезення пасажирів міжміського сполучення), відповідно до постанови: здійснення регулярних та нерегулярних перевезень пасажирів автомобільним транспортом у міському, приміському, міжміському, внутрішньообласному та міжобласному сполученні, зокрема пасажирські перевезення на міських автобусних маршрутах у режимі маршрутного таксі ${ }^{14}$, може бути як тимчасове припинення виконання зобов'язань сторонами, яке при певній тривалості дозволяє одній або двом сторонам розірвати договір, так і право сторони розірвати договір на самому початку.

В умовах пандемії має значення не тільки її наслідки стосовно виконання вже укладених договорів, а й правильне визначення умов знову укладених договорів. Наскільки довго триватиме кризова ситуація 3 COVID-19 поки незрозуміло, ситуація постійно змінюється, державами вводяться нові обмежувальні заходи, організації та підприємці також змушені враховувати нові реалії економічної діяльності, в тому числі і невизначеність ситуації. У такій обстановці особливо важливим стає правильний розподіл ризиків між контрагентами. Учасникам обороту потрібно задуматися про включення в договори спеціальних умов щодо ризиків, зв'язаних з пандемією, також сторони мають право не тільки передбачити порядок взаємодії в форс-мажорній ситуації, а й заздалегідь, з урахуванням всіх ризиків, передбачити можливість перерозподілу їх і відшкодування при настанні певних обставин, не пов'язаних з порушенням зобов'язань. 
${ }^{1}$ Цвайгерт К., Кетц Х. Введение в сравнительное правоведение в сфере частного права. Москва: Международ. отношения, 2000. Т. 2. $480 \mathrm{c}$.

2 Про захист населення від інфекційних хвороб: Закон України від 6.04.2000 р. Відомості Верховної Ради Украӥни. 2000. № 29. Ст. 228.

3 Про внесення змін до деяких законодавчих актів України, спрямованих на запобігання виникнення і поширення коронавірусної хвороби (COVID-19): Закон України від 17.03.2020 p.

${ }^{4}$ Иоффе О.С. Ответственность по советскому гражданскому праву. Ленинград: Изд-во Ленинградского ун-та, 1955.311 с.

5 Рахмилович В.А. О противоправовности как основании гражданской ответственности. Советское государство и право. 1964. № 3. C. 58-59.

6 Ойгензихт В.А. Проблема риска в гражданском праве. Душанбе, 1972. 224 с.

7 Коновалов С.А. Основание гражданско-правовой ответственности. Москва, 2006. 246 с.

8 Мельник О.О. (Застереження про незмінність обставин договору та форс-мажор у цивільному праві України. Национальный юридический журнал: теория и практика. 2016. № 2/1 (18). С. 76-78.

9 Попов Н.В. Теоретические и практические вопросы изменения и расторжения гражданско-правового договора в связи с изменением обстоятельств. Москва, 2003, 170 с.

10 Мельник О.О., Харитонова С.О. Класифікація ризиків у цивільному праві України. Нова редакиія Конституції України та вдосконалення цивільного законодавства: проблеми гармонізації: матеріали круглого столу. Одеса: Фенікс, 2013.

11 Лиховидов К. Риск как условие дифференциации и объема мер юридической ответственности. Законность, 2001. 129 с.

12 Про торгово-промислові палати в Україні: Закон України від 2.12.1997 р. Відомості Верховної Ради України. 1998. № 13. Ст. 52.

13 Цивільний кодекс України від 16.01.2003 р. Відомості Верховної Ради Украӥни. 2003. № № 40-44.

14 Про внесення змін до деяких законодавчих актів України, спрямованих на забезпечення додаткових соціальних та економічних гарантій у зв’язку з поширенням коронавірусної хвороби (COVID-19) (2020): Закон України № 540-IX від 30.03.2020 р.

\title{
Резюме
}

Мельник О.О. Зміна та розірвання договору у випадку дії обставин форс-мажору внаслідок пандемії.

Форс-мажор (непереборна сила) може бути причиною істотної зміни обставин, що $\epsilon$ підставою для розірвання або зміни договору i, у кінцевому рахунку, призводить до припинення зобов' язання (його розірвання) або збереження зобов'язання у зміненому вигляді.

Правове регулювання правових наслідків істотної зміни обставин, які існують при укладенні договору, як правило, будується на основі одного $з$ двох ключових принципів договірного права: принципу, згідно $з$ яким договори мають виконуватись (pacta sunt servanda), або застереженні про незмінність обставин (clausula rebus sic stantibus). У законодавстві зарубіжних країн містяться норми, відповідно до яких «зміна обставин може бути виправданням зміни договору, коли збереження договору у первісному вигляді призводить до надзвичайних результатів, не сумісних із справедливістю».

Нині в нашій країні, як і у багатьох країнах світу, склалася ситуація, яка унеможливлює виконання договірних зобов'язань, пов'язаних із запровадженням країнами загальнонаціональних карантинів у зв'язку із пандемією коронавірусної хвороби (COVID-19). Уряд нашої держави також вдався до врегулювання ситуації, яка склалася із запровадженням карантину на території України.

Ключові слова: форс-мажор, непереборна сила, укладення договору, зміна договору, розірвання договору, умови, зобов'язання, пандемія.

\section{Резюме}

\begin{abstract}
Мельник О.О. Изменение и расторжение договора в случае действия обстоятельства форс-мажора в результате пандемии.

Форс-мажор (непреодолимая сила) может быть причиной существенного изменения обстоятельств, являющихся основанием для расторжения или изменения договора, и, в конечном счете, приводит к прекращению обязательства (его расторжения) или сохранение обязательства в измененном виде.

Правовое регулирование правовых последствий существенного изменения обстоятельств, которые существуют при заключении договора, как правило, строится на основе одного из двух ключевых принципов договорного права: принципа, согласно которому договоры должны выполняться (pacta sunt servanda), или оговорке о неизменности обстоятельств (clausula rebus sic stantibus). В законодательстве зарубежных стран содержатся нормы, согласно которым «изменение обстоятельств может быть оправданием изменения договора, если сохранение договора в первоначальном виде приводит к чрезвычайным результатам, не совместимых со справедливостью».

На сегодняшний день в нашей стране, как и во многих странах мира, сложилась ситуация, которая делает невозможным выполнение договорных обязательств, связанных с введением странами общенациональных карантинов в связи с пандемией коронавирусной болезни (COVID-19). Правительство нашего государства также обратился к урегулированию ситуации, сло-
\end{abstract} жившейся с введением карантина на территории Украины.

Ключевые слова: форс-мажор, непреодолимая сила, заключение договора, изменение договора, расторжение договора, условия, обязательства, пандемия.

\section{Summary}

Olga Melnyk. Change and termination of the agreement in case of force major circumstances due to the pandemic.

Force majeure can cause a significant change in circumstances, which is the basis for termination or change of the contract, and, ultimately, leads to the termination of the obligation (its termination) or the preservation of the obligation in a modified form. Legal regulation of the legal consequences of a significant change in the circumstances that exist at the conclusion of the contract is usually based on one of two key principles of contract law: the principle, according to which contracts must be performed (pacta sunt servan- 
$d a$ ), or clause (clausula rebus sic stantibus). The legislation of foreign countries contains rules, according to which "a change of circumstances may justify a change in the contract, when the preservation of the contract in its original form leads to extraordinary results, incompatible with justice". The main consequences of a significant change in the circumstances that guided the parties in concluding the contract are:

- actually change the contract, ie change the terms of the contract (and as a consequence - the obligations between the parties) while maintaining the contract in force;

- and termination of the contract by agreement of the parties.

If the parties do not agree to bring the contract in line with the circumstances that have changed significantly, or to terminate it, the contract may be terminated on the grounds, established by the Central Committee of Ukraine, amended by a court decision at the request of the interested party: at the conclusion of the contract the parties proceeded from the fact that such a change of circumstances will not occur; the change of circumstances is due to reasons, which the interested party could not eliminate after their occurrence with all the care and diligence, required of it.

Today, in our country, as in many countries around the world, there is a situation that makes it impossible to fulfill the contractual obligations related to the introduction of national quarantine in connection with the pandemic of coronavirus (COVID-19). The government of our state has also resorted to resolving the situation with the introduction of quarantine on the territory of Ukraine.

Key words: Force majeure, force majeure, conclusion of a contract, change of a contract, termination of a contract, conditions, obligations, pandemics.

DOI: $10.36695 / 2219-5521.4 .2020 .43$

УДК 349.2

\section{Н.А. ЦИГАНЧУК, Р.Д. ЛЯШЕНКО, В.В. КАЛЕНЮК}

Наталія Антонівна Циганчук, кандидат юридичних наук, доцент*

ORCID: 0000-0002-1916-6524

Руслана Дмитрівна Ляшенко, кандидат юридичних наук, доцент, завідувач кафедри Поліського національного університету**

ORCID: 0000-0002-6129-7907

Вікторія Вікторівна Каленюк, студентка магістратури Поліського національного університе$m y^{* * *}$

\section{АУТСОРСИНГ ТА АУТСТАФІНГ: СУТНІСТЬ ТА ПРАКТИКА РЕАЛІЗАЦІЇ}

Постановка проблеми. Аутсорсинг та аутстафінг є актуальними конструкціями в правовій системі будь-якої держави, що вимагають належного законодавчого врегулювання. Їх особливість полягає у специфічних формах трудових правовідносин між замовниками послуг та виконавцями. До цього часу дане питання не врегульовано належним чином на законодавчому рівні в Україні, внаслідок чого суб' єкти підприємництва вимушені звертатися до узагальнюючих норм законодавства. Таким чином, існує потреба у дослідженні особливостей нормативного врегулювання питання аутсорсингу та аутстафінгу, а також визначення більш ефективної моделі трудової взаємодії.

Аналіз останніх досліджень і публікацій. Проблеми законодавчого регулювання аутсорсингу та аутстафінгу досліджено у наукових публікаціях таких вітчизняних учених, як: С. Бєляєва, С. Вавженчук, В. Вітко, О. Крушельницька, О. Кужелєв, Є. Цатурян, С. Цимбалюк та ін. Крім того, до даної проблематики неодноразово звертаються юристи-практики (Н. Загрія, Д. Стадник та ін.).

Визначення спільних та відмінних рис між аутсорсингом та аутстафінгом досліджено у працях: Т. Галайди, М. Іншиної, А. Товстохатька, Г. Чанишевої, В. Щербини та ін. У зв’язку із чим висловлювалися різноманітні підходи до їх розуміння.

Не зважаючи на наявність значної кількості праць, присвячених окремим аспектам аутсорсингу та аутстафінгу, існує потреба у визначенні їх ключових характеристик та ефективних форм взаємодії між окремими суб' єктами.

Формулювання мети статті. Мета даної статті полягає у дослідженні основних правових аспектів регулювання відносин, що пов'язані з аутсорсингом та аутстафінгом.

(C) Н.А. Циганчук, Р.Д. Ляшенко, В.В. Каленюк, 2020

${ }^{*}$ Nataliia Tsyganchuk, Ph.D. in Law, Associate Professor

${ }^{* *}$ Ruslana Liashenko, Ph.D. in Law, Associate Professor, Head of Department of Polissia National University

*** Viktoriia Kaleniuk, student of II year of the Master's degree of Polissia National University 